\title{
Bonding of CAD/CAM lithium disilicate restorations with regular and flowable composite resin with and without wetting resin
}

\author{
Greciana Bruzi ${ }^{1,6^{*}} \mathbb{D}$, Adriana Oliveira Carvalho², Marcelo Giannini ${ }^{3}$, Hamilton Pires Maia ${ }^{4}$ and Pascal Magne ${ }^{5}$
}

\author{
*Correspondence: \\ greciana.brasil@unifal-mg. \\ edu.br; kikaodonto@yahoo. \\ com.br \\ ${ }^{6}$ St. Figueira da foz, 44. Aldeia \\ de Sagres, 37200-000 Lavras, \\ MG, Brazil \\ Full list of author information \\ is available at the end of the \\ article
}

\begin{abstract}
Objectives: Assess the effect of applying a low viscosity resin before placing ceramic restoration with two different luting agent.

Materials and methods: Twenty slices from IPS e.max CAD (Ivoclar Vivadent) were fired and assigned to 5 treatment surface groups; E: hydrofluoric acid (HF); E/S: HFetching + silane (20 s); E/S+: HF-etching + silane (60 s); S: silane (20 s); S+: silane (60 s). Before building the cylinder with regular or flowable composite resin for the SBS test, half of each treatment surface group received adhesive (Optibond FL bottle \#2), and the other half no adhesive. The SBS test was performed after $24 \mathrm{~h}$. Statistical analysis was performed using multifactorial analyses of variance Two-way ANOVA. The Tukey HSD test was used to test the average values of all groups. The significance level adopted in all analyses was $\leq 0.05(p<0.05)$.

Results: Groups E/S and E/S+, with flowable + adhesive and E/S with regular composite resin + adhesive, showed the highest SBS values $(22.05,18.91$ and $21.06 \mathrm{MPa}$ respectively), followed by group E with or without adhesive, for both luting agent. The lowest bond strength was observed when the silane was applied alone, independent of the adhesive coat and luting agent $(0.65-5.55 \mathrm{MPa})$. When the adhesive was omitted, flowable presented high bond strength compared to composite resin in groups ES and ES+.
\end{abstract}

Conclusions: The low viscosity resin in the etched and silanized ceramic surface is important to obtain high SBS values.

Keywords: Adhesion, Silane, Lithium disilicate

\section{Introduction}

A reliable bonding to ceramic restoration can be obtained by the association of factors as well as ceramic topography and chemical adhesion [1-3]. Regarding the surface characteristic, the silica-based ceramic can be easily modified by the hydrofluoric-acid etching (HF) which is able to create micro-mechanical retention by the selective dissolution of the glassy phase. 1 . The further step is the silanization that takes care of the chemical adhesion between two different components (ceramic and resin) that need to be linked [2-5]. When silane agent coupling is applied, multiple layers are forming in the ceramic surface, among these layers, the physisorbed and chemisorbed regions consists in loosely bound oligomers thus that can be easily hydrolyzed and affect negatively the

(c) The Author(s) 2018. This article is distributed under the terms of the Creative Commons Attribution 4.0 International License (http://creativecommons.org/licenses/by/4.0/), which permits unrestricted use, distribution, and reproduction in any medium, provided you give appropriate credit to the original author(s) and the source, provide a link to the Creative Commons license, and indicate if changes were made. 
restoration durability. Therefore, it was suggested to remove these outermost layers by hot air drying and rinsing with hot water [6-10]. The luting step is followed by the direct application of the resin cement in the inner etched and silanated ceramic surface. Some clinicians may omit using the adhesive resin to wet the surfaces. However, depending on the viscosity, the luting agent may not be able to fill in all the micrometric spaces (microretentions) created by the HF-etching. The aim of applying a low-viscosity material is to create an interlocking that affects the resin-ceramic bond [11, 12], but these effects still require investigation. Another parameter is the choice of the luting agent, which may influence not only the bond strength but also vary in the degradation process [13, 14]. Regular restorative composite resin used as a luting agent can present some advantages over resin cement as well as degradation resistance and color stability [15-24] and can also compensate for little cracks or imperfections in the margins [24]. However, the viscosity of the composite resin is higher compared to resin cement, because of the higher filler content, which in turn might influence the ability to penetrated the microretentions of the etched ceramic. The purpose of this study was to assess the effect of wetting with adhesive resin before placing ceramic restorations with different luting agent, regular versus flowable composite resins. The first null hypothesis tested was that various treatments (etching, silane, wetting resin) do not affect the bond strength. The second null hypothesis was that the luting agent (restorative versus flowable) does not make a difference.

\section{Materials and methods}

\section{Specimen preparation}

Twenty slices $(14 \times 16 \times 2 \mathrm{~mm})$ of IPS e.max CAD (EMAX; Ivoclar Vivadent, AG, Schann, Liechtenstein) were obtained by sectioning CAD/CAM blocks with a slowspeed diamond water-cooled saw (Isomet, Buehler, Lake Bluff, IL, USA). The slices were crystalized in a ceramic furnace (Austromat 624; DEKEMA Dental-Keramiköfen GmgH, Freilassing, Germany) following the manufacturer's instructions. All the slices were embedded in an acrylic resin positioning base (Palapress; Heraeus Kulzer, Hanau, Germany) and polished with 400- and 600-grit silicon carbide paper under water cooling. The surfaces of all slices were then cleaned in an ultrasonic bath in distilled water during 5 min.

\section{Surface treatments}

Five surface conditioning methods were applied: E-5\% HF-etching (IPS Ceramic Etching Gel, Ivoclar Vivadent, AG, Schann, Liechtenstein) for $20 \mathrm{~s}$, rinsing with air/water spray for $60 \mathrm{~s}$ followed by post-etching cleaning in ultrasonic bath in distilled water for $2 \mathrm{~min}$; E/S-5\% HF-etching as above, silane (Silane, Ultradent, South Jordan, Utah, USA) applied for $20 \mathrm{~s}$ and air dried for $20 \mathrm{~s}$, hot air dried at $60^{\circ} \mathrm{C}$ for $20 \mathrm{~s}$ (with hair dryer at $10 \mathrm{~cm}$-distance); E/S+-5\% HF-etching as above, silane applied for $60 \mathrm{~s}$, air dried for $20 \mathrm{~s}$ and hot air dried $60^{\circ} \mathrm{C}$ for $20 \mathrm{~s}$ rinsed with boiling water for $15 \mathrm{~s}$ and hot air dried for another $20 \mathrm{~s}$; $\mathrm{S}$-no etching, silane for $20 \mathrm{~s}$ followed by air dried for $20 \mathrm{~s}$, hot air dried at $60{ }^{\circ} \mathrm{C}$ for $20 \mathrm{~s}$ or $\mathrm{S}+-$ no etching, silane applied for $60 \mathrm{~s}$, air dried for $20 \mathrm{~s}$ and hot air dried $60^{\circ} \mathrm{C}$ for $20 \mathrm{~s}$, rinsed with boiling water for $15 \mathrm{~s}$ and another hot air dried for $20 \mathrm{~s}$. 


\section{SBS test}

Specimens were then placed in a positioning device and a Teflon mold (Ultradent Jig, South Jordan, Utah, USA) containing a bonding area $0.04448 \mathrm{~cm}^{2}$ was used. Half of each group received adhesive resin coating (Optibond FL bottle \#2, Kerr Corp. Orange, CA, USA) and for the other half no adhesive was applied. The cylinders for SBS test were built either with regular composite resin (Z100, 3M ESPE, Saint Paul, MN, USA) or flowable composite resin Filtek Supreme Ultra, 3M ESPE, Saint Paul, MN, USA) (Tables 1, 2) inserted into the Teflon mold in two increments of approximately $1.8 \mathrm{~mm}$ each, using a small condensing spatula and light polymerized for $20 \mathrm{~s}$ (Valo, Ultradent, South Jordan, Utah, USA) at $1000 \mathrm{~mW} / \mathrm{cm}^{2}$. Six resin cylinders (diameter: $2.4 \mathrm{~mm}$ ) were built onto each ceramic slice (length: $15 \mathrm{~mm}$, width: $4 \mathrm{~mm}$, thickness: $2 \mathrm{~mm}$ ), $3.5 \mathrm{~mm}$ apart, resulting in 12 specimens per group. The test was performed after $24 \mathrm{~h}$ of storage in distilled water. All samples were submitted to SBS testing (Shear Bond Tester; Bisco Inc., Schaumburg, IL, USA) with a ramp load of $43.8-\mathrm{kg}$-force $/ \mathrm{min}$. The failure mode was assessed by macro-photography (Nikon D60 and Sigma Lens 105 mm and a teleconverter $2 \times$, Vivitar).

\section{Statistical analysis}

The mean bond strength and standard deviation were calculated for all groups. Statistical analysis was performed using multifactorial analyses of variance Two-way ANOVA. The Tukey HSD test was used to test the average values of all groups. The significance level adopted in all analyses was $\leq 0.05(\mathrm{p}<0.05)$ (Table 3$)$.

\section{Results}

All SBS means and standard deviation are presented in Table 4. The comparison between groups where restorative composite resin was used as a luting agent showed higher SBS values for $\mathrm{ES}$ with adhesive, followed by $\mathrm{E}=\mathrm{ES}+$ with and without adhesive. No statistical differences were found between E, ES and ES+ when the adhesive was omitted. However not wetting with adhesive showed a significant decrease in bond strength for $\mathrm{ES}$ and $\mathrm{ES}+$, while for $\mathrm{E}$ the values were not statistically different. When flowable composite resin was used as a luting agent the highest SBS value were obtained with ES

Table 1 Materials tested, brand name, manufacturer and composition

\begin{tabular}{|c|c|c|c|}
\hline Materials & Brand name & Manufacturer & Composition \\
\hline HF & IPS ceramic etching gel & Ivoclar Vivadent & Hydrofluoric acid 2.5 to $<7 \%$ \\
\hline Silane & Silane & Ultradent & $\begin{array}{l}\text { Methacryloxy propyl trimethoxy silane; } \\
\text { isopropyl alcohol }\end{array}$ \\
\hline Ceramic & IPS e.max CAD & Ivoclar Vivadent & $\begin{array}{l}\mathrm{SiO}_{2} ; \mathrm{Li}_{2} \mathrm{O} ; \mathrm{K}_{2} \mathrm{O} ; \mathrm{P}_{2} \mathrm{O}_{5} ; \mathrm{ZrO}_{2} ; \mathrm{ZnO} ; \mathrm{Al}_{2} \mathrm{O}_{3} ; \\
\quad \mathrm{MgO} ; \text { Colouring oxides }\end{array}$ \\
\hline Adhesive & Optibond FL (bottle \#2) & Kerr Corp. & $\begin{array}{l}\text { 2-Hydroxyethyl methacrylate; 3-trimeth- } \\
\text { oxysilylpropyl methacrylate; 2-hydroxy- } \\
\text { 1,3-propanediyl bismethacrylate; alkali } \\
\text { fluorosilicates( } \mathrm{Na})\end{array}$ \\
\hline Regular composite resin & Z100 & 3M ESPE & $\begin{array}{l}\text { Bis-GMA and TEG-DMA; inorganic matrix; } \\
\text { zirconia/silica }\end{array}$ \\
\hline Flowable composite resin & Filtek supreme ultra & 3M ESPE & $\begin{array}{l}\text { Bis-GMA, UDMA, TEGDMA, and bis-EMA; } \\
\text { inorganic matrix: zirconia/silica }\end{array}$ \\
\hline
\end{tabular}




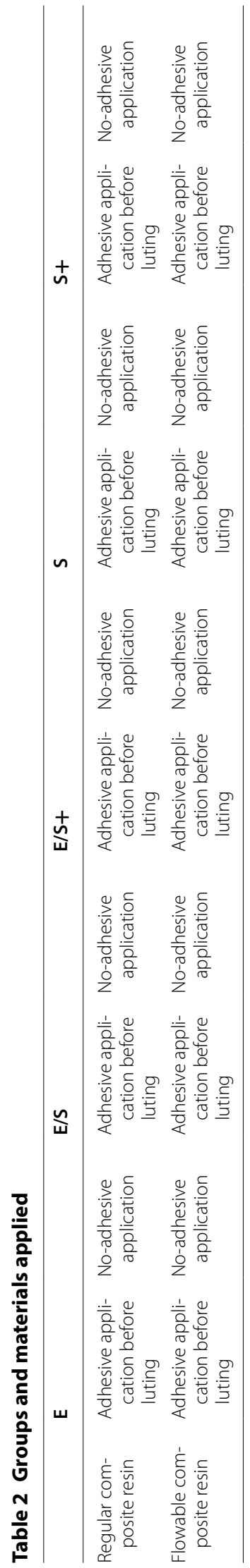


Table 3 Statistical datas

\begin{tabular}{lrrrrll}
\hline Source & DF & \multicolumn{1}{c}{ SS } & MS & F & PROB $>$ F & Omega squared \\
\hline Among treatments & 9 & 9877.959 & 1097.551 & 94.160 & 0.000 & 0.734 \\
$\begin{array}{l}\text { Among composite } \\
\quad 1\end{array}$ & 242.225 & 242.225 & 20.781 & 0.000 & 0.017 \\
$\quad$ resin and flowable & & & & & & \\
Interaction & 9 & 626.287 & 69.587 & 5.970 & 0.000 & 0.039 \\
Within groups & 220 & 2564.362 & 11.656 & & & \\
Total & 239 & $13,310.833$ & 55.694 & & & \\
\hline
\end{tabular}

Table 4 Different lowercase letter in the same column are statistically different

\begin{tabular}{lcc}
\hline Treatments & Regular composite resin & $\begin{array}{l}\text { Flowable } \\
\text { composite } \\
\text { resin }\end{array}$ \\
& $\begin{array}{l}\text { Mean (SD) } \\
(\mathbf{n = 1 2 )}\end{array}$ & $\begin{array}{l}\text { Mean (SD) } \\
\text { (n=12) }\end{array}$ \\
\hline E & $15.15(3.8) \mathrm{bA}$ & $13.13(2.4) \mathrm{bA}$ \\
$\mathrm{E} / \mathrm{S}$ & $21.06(4.4) \mathrm{aB}$ & $18.91(3.6) \mathrm{aB}$ \\
E/S+ & $15.93(4.0) \mathrm{bC}$ & $22.05(3.9) \mathrm{aD}$ \\
S & $4.32(5.1) \mathrm{dE}$ & $4.85(2.9) \mathrm{dE}$ \\
S+ & $3.92(2.5) \mathrm{dF}$ & $5.55(3.3) \mathrm{dF}$ \\
E (no adhesive) & $11.79(5.2) \mathrm{bcG}$ & $11.04(6.2) \mathrm{bG}$ \\
E/S (no adhesive) & $10.88(3.2) \mathrm{bcH}$ & $17.22(1.1) \mathrm{bcl}$ \\
E/S+ (no adhesive) & $10.13(1.0) \mathrm{cJ}$ & $17.01(1.4) \mathrm{bcK}$ \\
S (no adhesive) & $0.65(2.4) \mathrm{dL}$ & $3.31(1.8) \mathrm{dL}$ \\
S+ (no adhesive) & $1.53(0.8) \mathrm{dM}$ & $2.41(1.7) \mathrm{dM}$
\end{tabular}

Different uppercase letter in the same line are statistically different

E hydrofluoric acid (HF), E/S HF-etching + silane (20 s), E/S+ HF-etching + silane (60 s), S silane (20 s), S+ silane (60 s)

and ES + with adhesive, followed by E. When the adhesive layer was not applied E, ES and ES + showed no statistical difference. The lowest SBS values were always obtained with $\mathrm{S}$ and $\mathrm{S}+$ regardless of the use of adhesive resin or type of luting agent. The comparison between the luting agents, revealed that for groups ES + with adhesive, ES and ES + without adhesive flowable composite resin yielded statistically higher results than restorative composite resin. When the adhesive was used, it was shown a continue adhesive gap, that was not clear in the groups without adhesive (Figs. 1, 2, 3, 4). The failure mode was always adhesive, leaving a clean ceramic surface (Fig. 5).

\section{Discussion}

The first null-hypothesis was rejected since the surface treatments affected the SBS values. The second null-hypothesis was rejected in part, as the luting agent had a significant influence on the SBS in groups ES+ with adhesive, ES and ES+ without adhesive. Etching alone and use of adhesive resin promoted similar bond strength, which can be explained by the micromechanical interlocking created by the luting agent or adhesive coat [25]. However, this work reaffirms the importance of associating the mechanical and chemical treatments to reach high bond strength as illustrated by E/S groups and application of the adhesive resin over the silanated surface to provides better infiltration 


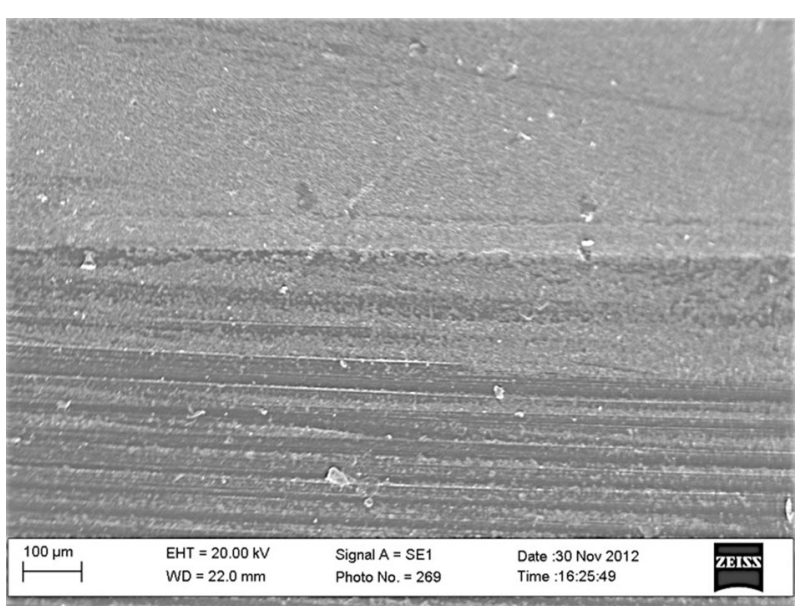

Fig. 1 Micrograph SEM of a cross-section from group with regular composite resin (CR) with adhesive

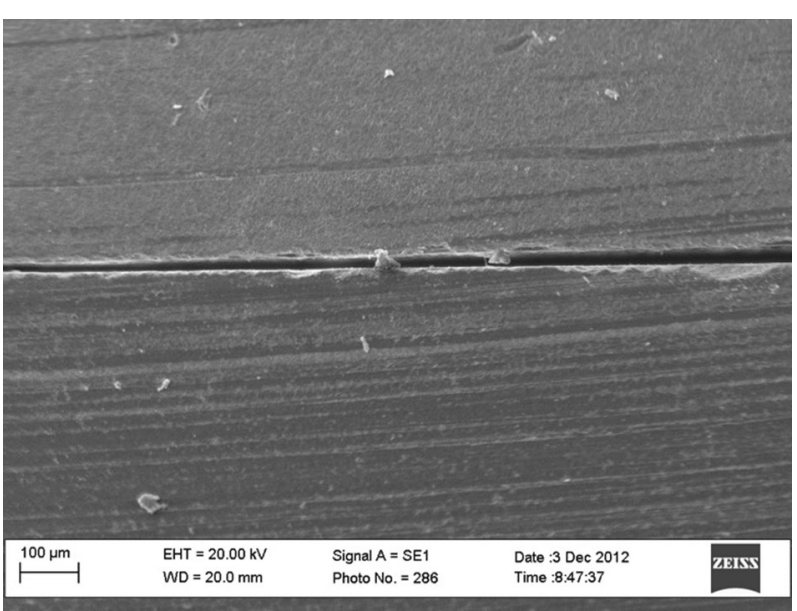

Fig. 2 Micrograph SEM of a cross-section from group with regular composite resin (CR) without adhesive

into the irregularities of the etched surfaces [11]. On the other hand, Passos et al. [12] did not find better results when applying the adhesive coat before the luting agent because they used a dual-cure resin cement which is flowable by nature. When using more viscous luting agents, however, the low viscosity resin seems to be indispensable to wet the etched and silanized ceramic surface, infiltrate in the micrometric spaces and ensure the ceramic bond strength by micromechanical interlocking [11, 25]. The omission of this step probably generated an insufficient penetration of the luting agent in the micro porosity and consequently decreases the ceramic mechanical strength [26]. These empty spaces can be an area of stress concentration since the adhesive layer work like an damper [27]. The lower bond strength obtained by silane alone, regardless of the use of adhesive resin and type of luting agent, can be explained by the absence of micromechanical retention in the ceramic surface, showing that the chemical step alone is not sufficient to obtain high bond strength. Regarding the luting agent, the similarity in bond 


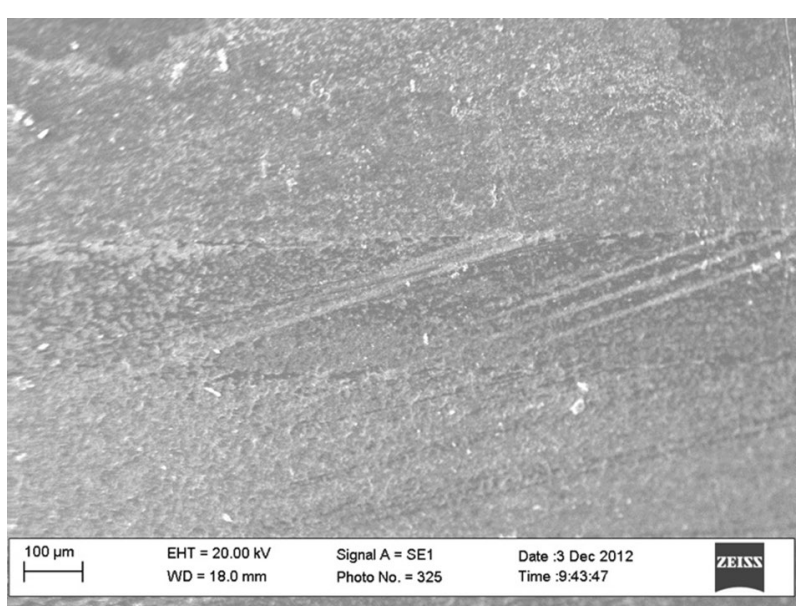

Fig. 3 Micrograph SEM of a cross-section from group with flowable composite resin (FL) with adhesive

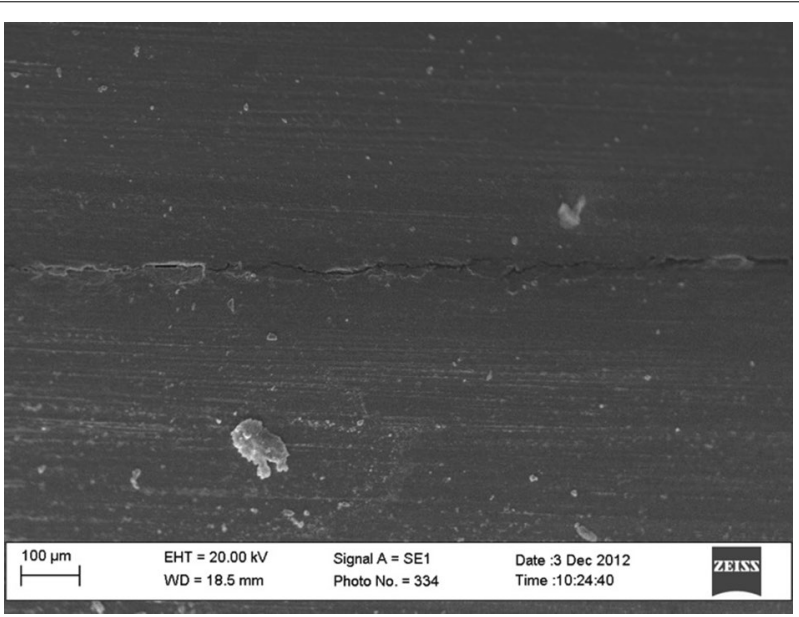

Fig. 4 Micrograph SEM of a cross-section from group with flowable composite resin (FL) without adhesive

strength between restorative and flowable composite resin could be explained by the fact that in this research the authors did not used pressure during the luting agent application. Seating pressure during luting could promote a better penetration of the resin into the ceramic retention. This study is restricted to some materials and did not evaluated the longevity of the SBS, thus more studies are suggested to compare the luting agent degradation in the course of time.

\section{Conclusion}

Wetting with adhesive resin increases the resin-ceramic SBS to the etched and silanated ceramic surface. This is particularly important when using a restorative composite resin as a luting agent. Omission of wetting resin will result in better SBS to the etched and silanated ceramic surface when using a flowable luting agent compared to a restorative composite resin. 


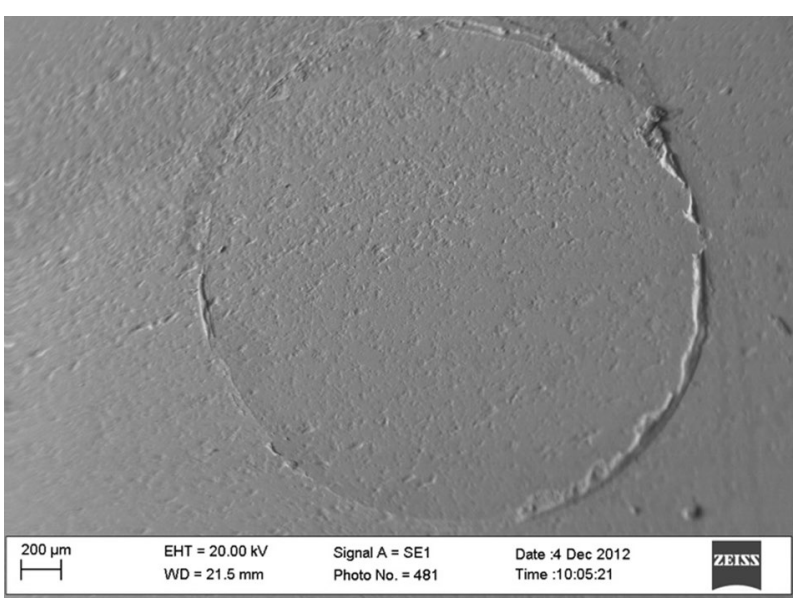

Fig. 5 Adhesive failure mode with clean ceramic surface

\section{Abbreviations}

CAD/CAM: computer-aided design and manufacturing; HF: hydrofluoric acid; SBS: shear bond strength; MPa: megapascal; s: seconds; ${ }^{\circ} \mathrm{C}$ : celcius degree; \%: percent; $\mathrm{mW} / \mathrm{cm}^{2}$ : miliwatts/centimeter squared; $\mathrm{mm}$ : millimeter; h: hour; $\mathrm{KgF}$ : kilogram force.

\section{Authors' contributions}

BG - Contribution to the paper: wrote the paper, performed the experiments in partial fulfillment of requirements for a degree. CAO_Contribution to the paper: Wrote the paper, performed the experiments in partial fulfillment of requirements for a degree. GM-Contribution to the paper: wrote the paper. MHP — Contribution to the paper: wrote the paper. MP_Contribution to the paper: idea, wrote the paper. All authors read and approved the final manuscript.

\section{Author details}

${ }^{1}$ Departament of Operative Dentistry, Federal University of Alfenas (UNIFAL-MG), Alfenas, MG, Brazil. ${ }^{2}$ Departament of Health 1, State University of Southwest Bahia, Vitória da Conquista, BA, Brazil. ${ }^{3}$ Department of Restorative Dentistry, Piracicaba School of Dentistry, Campinas State University, Piracicaba, SP, Brazil. ${ }^{4}$ Departament of Operative Dentistry, Fedrral University of Santa Catarina (UFSC), Florianópolis, SC, Brazil. ${ }^{5}$ Don and Sybil Harrington Professor of Esthetic Dentistry, Restorative Sciences, Herman Ostrow School of Dentistry, University of Southern California, Los Angeles, CA, USA. ${ }^{6}$ St. Figueira da foz, 44. Aldeia de Sagres, 37200-000 Lavras, MG, Brazil.

\section{Acknowledgements}

The authors wish to express their gratitude to Ivoclar Vivadent for providing IPS e.max CAD and IPS Ceramic Etching Gel; Kerr Crop. for providing Optibond FL Adhesive and Ultradent for providing Silane. Study supported in part by CAPES Foundation 4979/11-7 (Dr. Bruzi) and CNPq 20092/2011-6 (Dr. Carvalho).

\section{Competing interests}

The authors declare that they have no competing interests.

\section{Availability of data and materials}

Not applicable.

\section{Funding}

Not applicable.

\section{Publisher's Note}

Springer Nature remains neutral with regard to jurisdictional claims in published maps and institutional affiliations.

Received: 12 September 2018 Accepted: 20 November 2018

Published online: 04 December 2018

\section{References}

1. Della Bona A, van Noort R. Ceramic surface preparations for resin bonding. Am J Dent. 1998;11(6):276-80.

2. Roulet JF, Söderholm KJ, Longmate J. Effects of treatment and storage conditions on ceramic/composite bond strength. J Dent Res. 1995;74(1):381-7.

3. Jardel V, Degrange M, Picard B, Derrien G. Surface energy of etched ceramic. Int J Prosthodont. 1999;12(5):415-8. 
4. Bruzi G, Carvalho AO, Giannini M, Maia HP, Magne P. Post-etching cleaning influences the resin shear bond strength to CAD/CAM lithium-disilicate ceramics. Appl Adhes Sci. 2017;5(1):17.

5. Magne P, Bruzi G, Carvalho A, Enciso R, Giannini M. Optimization of heat-dried silane application for CAD/CAM ceramic resin bonding. Nanosci Nanotechnol. 2018;2(1):1.

6. Monticelli F, Toledano M, Osorio R, Ferrari M. Effect of temperature on the silane coupling agents when bonding core resin to quartz fiber posts. Dent Mater. 2006;22(11):1024-8.

7. Shen C, Oh WS, Williams JR. Effect of post-silanization drying on the bond strength of composite to ceramic. J Prosthet Dent. 2004;91(5):453-8.

8. Fabianelli A, Pollington S, Papacchini F, Goracci C, Cantoro A, Ferrari M, van Noort R. The effect of different surface treatments on bond strength between leucite reinforced feldspathic ceramic and composite resin. J Dent. 2010;38(1):39-43.

9. Filho AM, Vieira LC, Araújo E, Monteiro Júnior S. Effect of different ceramic surface treatments on resin microtensile bond strength. J Prosthodont. 2004;13(1):28-35.

10. Hooshmand T, van Noort R, Keshvad A. Bond durability of the resin-bonded and silane treated ceramic surface. Dent Mater. 2002;18(2):179-88.

11. Naves LZ, Soares CJ, Moraes RR, Gonçalves LS, Sinhoreti MA, Correr Sobrinho L. Surface/interface morphology and bond strength to glass ceramic etched for different periods. Oper Dent. 2010;35(4):420-7.

12. Passos SP, Valandro LF, Amaral R, Ozcan M, Bottino MA, Kimpara ET. Does adhesive resin application contribute to resin bond durability on etched and silanized feldspathic ceramic? J Adhes Dent. 2008;10(6):455-60.

13. Osorio R, Castillo-de Oyagüe R, Monticelli F, Osorio E, Toledano M. Resistance to bond degradation between dualcure resin cements and pre-treated sintered CAD-CAM dental ceramics. Med Oral Patol Oral Cir Bucal. 2012;17(4):e669-77.

14. Liu Q, Meng X, Yoshida K, Luo X. Bond degradation behavior of self-adhesive cement and conventional resin cements bonded to silanized ceramic. J Prosthet Dent. 2011;105(3):177-84.

15. Besek M, Mörmann WH, Persi C, Lutz F. The curing of composites under Cerec inlays. Schweiz Monatsschr Zahnmed. 1995;105(9):1123-8.

16. Daronch M, Rueggeberg FA, De Goes MF. Monomer conversion of pre-heated composite. J Dent Res. 2005;84(7):663-7.

17. Daronch M, Rueggeberg FA, De Goes MF, Giudici R. Polymerization kinetics of pre-heated composite. J Dent Res. 2006;85(1):38-43.

18. Wagner WC, Aksu MN, Neme AM, Linger JB, Pink FE, Walker S. Effect of pre-heating resin composite on restoration microleakage. Oper Dent. 2008;33(1):72-8.

19. Fróes-Salgado NR, Silva LM, Kawano Y, Francci C, Reis A, Loguercio AD. Composite pre-heating: effects on marginal adaptation, degree of conversion and mechanical properties. Dent Mater. 2010;26(9):908-14.

20. Lucey S, Lynch CD, Ray NJ, Burke FM, Hannigan A. Effect of pre-heating on the viscosity and microhardness of a resin composite. J Oral Rehabil. 2010;37(4):278-82.

21. Mundim FM, Garcia Lda F, Cruvinel DR, Lima FA, Bachmann L, Pires-de-Souza F de C. Color stability, opacity and degree of conversion of pre-heated composites. J Dent. 2011;39(Suppl 1):e25-9.

22. Deb S, Di Silvio L, Mackler HE, Millar BJ. Pre-warming of dental composites. Dent Mater. 2011;27(4):e51-9.

23. Magne P, Razaghy M, Carvalho MA, Soares LM. Luting of inlays, onlays, and overlays with preheated restorative composite resin does not prevent seating accuracy. Int J Esthet Dent. 2018;13(3):318-32.

24. Lohbauer U, Zinelis S, Rahiotis C, Petschelt A, Eliades G. The effect of resin composite pre-heating on monomer conversion and polymerization shrinkage. Dent Mater. 2009;25(4):514-9.

25. Peumans M, Van Meerbeek B, Yoshida Y, Lambrechts P, Vanherle G. Porcelain veneers bonded to tooth structure: an ultra-morphological FE-SEM examination of the adhesive interface. Dent Mater. 1999;15(2):105-19.

26. Mecholsky JJ Jr. Fractography: determining the sites of fracture initiation. Dent Mater. 1995;1 1(2):113-6.

27. Lastumäki TM, Lassila LV, Vallittu PK. The semi-interpenetrating polymer network matrix of fiber-reinforced composite and its effect on the surface adhesive properties. J Mater Sci Mater Med. 2003;14(9):803-9.

\section{Submit your manuscript to a SpringerOpen ${ }^{\circ}$ journal and benefit from:}

- Convenient online submission

- Rigorous peer review

- Open access: articles freely available online

- High visibility within the field

- Retaining the copyright to your article

Submit your next manuscript at $\gg$ springeropen.com 